\title{
The distribution of skills among the European adult population and unemployment: a comparative approach
}

\section{Introduction}

The most painful effect of the Great Recession in European countries has been the surge in unemployment rates, which have had obvious macro and microeconomic implications in terms of both economic efficiency and equality. The intensity of these effects have varied depending on such factors as welfare state coverage (Gottschalk and Smeeding, 1997), the strength of unions (Donado and Wälde, 2012) and the size of the informal labour market (Bosch and Esteban-Pretel, 2012). Although the general European panorama has deteriorated since 2008, with a slight improvement since 2012, Figure 1 shows considerable heterogeneity across European countries.

<INSERT FIGURE 1 AROUND HERE>

Two notable features of the economic crisis in Europe have been the increase in income inequality $^{1}$ (OECD, 2011; De Beer, 2012) and the heterogeneous pattern of this inequality by educational level (Gesthuizen et al., 2011) ${ }^{2}$. Thus, workers with low levels of educational attainment were among the first to lose their jobs. This phenomenon has been especially intense in countries such as Spain, where a large part of the labour force was employed in low value-added activities associated with the real estate or

1 However, Agnello and Sousa (2012) and Reich (2010) find that income inequality tends to increase before financial crises.

2 Gebel and Giesecke (2011) analysed a set of 15 European countries for the 1992-2007 period and found no evidence of an increase in the skills-related unemployment gap. 
tourism sectors. Indeed, these economic sectors provided a means of escape from unemployment to low-skilled workers in (notably Southern) European countries with a qualification structure below that of the EU average. For instance, in 2012 , only $55.2 \%$ of Spain's active population had successfully completed post-compulsory studies compared to an average figure across the EU of $74.2 \%$.

The positive relationship between education and labour market outcomes, including such characteristics as occupation and salary, has been comprehensively verified (Psacharopoulos and Patrinos, 2004). Two main lines of argument have been developed in explanation of this relationship: on the one hand, human capital theory (Becker, 1962) links better labour market outcomes to the greater productivity of more educated workers, a characteristic enhanced through formal education; on the other, various authors highlight the role played by education in signalling the most productive workers (Spence, 1973). Both theories probably go some way to explaining the higher unemployment rates among low-educated Europeans and, consequently, disentangling the extent of both effects (i.e., enhanced skills and signalling functions of education) is an essential exercise for the design of effective educational policies aimed at increasing the possibilities of finding work in a high unemployment environment. This paper explores the existence of heterogeneous employment situations across the countries of Europe and seeks to provide evidence of the respective impacts of the two effects discussed.

If skill levels have an impact on labour market status, then we face a clear question of equity, as inequalities in the distribution of skills will result in inequalities in labour market opportunities. Indeed, the acquisition of skills by the adult population - and, subsequently, the probability of being unemployed - depends, among other factors, on the level of human capital of the previous generation (Jäntti and Jenkins, 2015). 
The contribution of this paper, therefore, is twofold, as it addresses two main research questions: first, it estimates the importance of the level of skills and education on the probability of being unemployed; and, second, it provides evidence of the impact of inequalities in the previous socioeconomic and cultural background of individuals on the probability of being unemployed. These two objectives are assessed using data for 24 jurisdictions participating in the first round of the OECD's Programme for the International Assessment of Adult Competencies (PIAAC) which provides rich information on the individual and labour characteristics of 16 - to 65-year-old adults. The PIAAC is a particularly useful tool for our analysis, as it includes the participants' results in assessments that measure their levels of numeracy, literacy and problem-solving, which can be understood as proxy variables for potential productivity and that allow us to control for the signalling effect of education.

The rest of the article is structured as follows: first, we provide a brief overview of its theoretical framework and then we describe the data and methodology employed. Next we present and discuss the results; and, finally, we summarize the study's main conclusions.

\section{Education, skills and labour market outcomes}

The close relationship established between education and economic growth has been analysed from both macro and micro perspectives. Macro analyses, such as Barro (1996) and Krueger and Lindahl (2001), stress the positive relationship between a country's level of human capital and its level of economic growth. From a microeconomic perspective, it is well documented that better educated workers enjoy monetary (Mincer,

1958) and non-monetary (Ricci and Zachariadis, 2013; Dickson and Harmon, 2011) benefits. Studies such as Hanushek et al. (2015) have looked into these aspects using 
PIAAC data. Those who successfully complete higher levels of education have less probability of being excluded from the labour market and usually enjoy improved working conditions (Strauss and Leuze, 2013). Moreover, highly educated workers tend to be more productive, an outcome for which the two main theories presented above (i.e., human capital and signalling) offer different explanations, although they should perhaps not be seen as being exclusive. The OECD (2014a) states that proficiency in literacy has a strong relationship with NEET status, regardless of age, and suggests that the signalling role of education among young workers may decline as employers learn about//employers come to appreciate the workers' true productivity. However, such employer learning is not observed in all countries.

Evidence for the predominance of one or other explanation is scarce and inconclusive (Clark and Martorell, 2014). Indeed, achieving a better understanding of the respective explanatory powers of these two theories is clearly a relevant exercise for policy makers that seek to design effective educational and training policies to help boost occupation. This acquires particular relevance in an environment marked by economic crisis.

The effectiveness of educational policies has to face several limitations: first, human capital must be applied to a stock of physical capital that may or may not be available in the country; second, their impact operates in the long run; third, they are dependent on the interaction of a set of other labour supply factors (including demographic shifts and migration flows) with labour demand factors (sectorial structure, technological changes or changes in openness to trade, among others). In any event, education is a key determinant of labour status and this has become especially evident in Europe during the Great Recession.

During the 2008-2012 period, unemployment rates grew in all the EU-28 countries, without exception. The situation was especially acute among Southern Europe countries 
and low-skilled workers, whose unemployment rates increased at a faster pace than average. As a consequence, the unemployment gap by educational levels has widened since 2008 (Figure 2).

\section{$<$ INSERT FIGURE 2 AROUND HERE>}

Figure 2 highlights an additional important fact: this widening in the unemployment gap by educational levels was driven by the surge in unemployment of the low-educated group. This increase was more moderate for the highest and second highest level of education, the gap between them remaining relatively constant. There are a number of labour supply and demand factors behind this fact, and the combination of the different rates at which employment was destroyed in different industries and the persistence of over-education in many countries (Flisi et al., 2014; Morgado et al., 2015) play a relevant role in understanding it. However, the role of institutions should not be understated when explaining international differences in the labour market (Hanushek et al., 2015; Paccagnella, 2015). Indeed, Allen et al. (2013) and Adalet McGowan and Andrews (2015) argue that skill mismatches seem to be linked to the grade of flexibility in the labour market.

Adults with higher education endowments present higher levels in key competencies, making them more flexible to labour market changes (OECD, 2013a). Thus, it seems plausible to hypothesise that one of the main mechanisms via which highly educated adults enjoy better job opportunities is via their higher level of competencies. The OECD (2013b) shows the positive relationship between literacy and labour market participation, occupation and salaries, even after controlling for education: literacy "plays an important and independent role as a determinant of success in the labour market (2013b:227)". Increasing workers' skill levels, therefore, becomes a desirable objective in order to 
reduce unemployment rates. In other words, unemployment rates tend to be lower in countries with higher levels of competencies, as the accumulation of human capital allows the country to increase its productive capacity in the long run. The first objective of this paper, therefore, is to estimate the impact of workers' competencies on labour market opportunities.

However, the acquisition of competencies is a cumulative process and skills can be acquired via different channels, not only via formal education (Behaghel et al, 2014; OECD, 2013b). Among others, individual and family characteristics play a role in this process and, consequently, the distribution of these characteristics has an impact on the final distribution of competencies. The second objective of this paper, therefore, is to provide a better understanding of the relationship between the distribution of key variables - other than formal education - that have an impact on workers' endowment of competencies and their probability of being unemployed.

\section{Data and methodology}

The empirical evidence presented in this paper is derived from the OECD's PIAAC-2013 database. One of the main strengths of the programme is its comprehensive treatment of the lifelong acquisition of skills of adults aged between 16 and 65 years old. It provides information on those activities and situations that have an impact on the acquisition of skills (such as formal education), the use of skills and the characteristics of the workplace and lifelong learning activities. Additionally, PIAAC gathers information on the type of skills required for, and used in, the workplace, as well as detailed information on the personal, career and socio-cultural characteristics of all the participants. The survey was to be answered primarily using a computer but respondents could opt for paper and pencil questionnaires. Countries were required to use probability samples 
representative of the target population, that is, the non-institutionalised population residing in the country at the time of data collection (between August 2011 and March 2012).

Finally, PIAAC reports the scores achieved by adults from 26 jurisdictions in relation to three basic skills: literacy, numeracy and problem-solving ${ }^{3}$. Response rates ranged from $45 \%$ (Sweden) to $75 \%$ (Korea), most countries being in the $50 \%$ to $60 \%$ interval (OECD 2014b, chapter 10:4). Differences in sampling methods and response rates were adjusted by weighting, used throughout our analysis.

In our analysis we draw on information from 24 jurisdictions ${ }^{4}$. We refer to jurisdictions as opposed to countries because, in the case of Belgium, for example, only the Flemish community took part in the assessment and, in the case of the United Kingdom, PIAAC provides representative samples for England and Northern Ireland. The Canadian sample is also representative of both the English-speaking and the French-speaking provinces.

It should also be mentioned that in some jurisdictions, in order to respect national regulations, some variables are not provided or provided using alternative codes and categories. For example, countries such as Germany, Austria, Canada, Estonia and the United States do not provide information on the variable "years passed since the year of immigration to the country".

Two of the main features of PIAAC data are shared with another of the best known OECD databases, PISA. First, participants' performance in relation to three

3 Some jurisdictions did not report results for the three competencies.

4 We exclude Cyprus and Australia from the analysis due to restrictions in access to their microdata. Readers should note that the sample for the Russian Federation does not include the population of the Moscow municipal area. The data published, therefore, do not represent the entire resident population aged 16-65 in Russia but rather the population of Russia excluding the population in the Moscow municipal area. 
competencies is measured using a set of plausible values (5 in the case of PISA; 10 in that of PIAAC). Second, replicate weights are calculated using a similar method. In the case of PIAAC, however, data are not nested and they all belong to the same individual level ${ }^{5}$. In order to take these characteristics into account, we have employed the IDB Analyzer, a statistical tool provided by the OECD, for bivariant analyses, and piaacreg, a specific module for the statistical package Stata, which accelerates multivariate analyses - OLS and logistic regressions - with PIAAC. Basic labour market information (activity and unemployment rate) for the 24 jurisdictions analysed, together with information on skill differences between the employed and the unemployed, are given in tables A.1 and A.2 in the Appendix.

<INSERT FIGURE 3 AROUND HERE>

Interestingly, a first approach to the PIAAC data seems to show a negative relationship between skills and a country's level of unemployment (Figure 3). Figure 3 highlights considerable differences in unemployment rates across Europe, ranging from $3.3 \%$ in Norway to $25.2 \%$ in Spain, and in mean literacy skills. While countries such as Japan, Holland, Finland and Norway have low unemployment rates and high competency levels, countries such as Spain, Italy, France, Ireland and Poland present the opposite situation. This results in the aforementioned negative relationship between skills and a country's level of unemployment. However, this relationship needs to be interpreted with caution, for at least two reasons. First, the possible existence of reverse causation between unemployment and competency levels, i.e., lower unemployment rates may increase the level of competencies, as skills can be acquired in the workplace. Secondly,

5 A detailed description of the design of PIAAC can be found at OECD (2014b). 
Figure 3 describes an average trend, some countries deviating notably from it. For example, the population of Sweden and Norway had a similar level of reading competencies but the unemployment rate in the former was double that of the latter. Similar situations can be found when comparing other countries with similar levels of skills, such as Spain and Italy, or Korea and the Slovak Republic. Therefore, Figure 3 shows the importance of skills as a determinant of employment and reveals the existence of other factors - a country's economic structure, or the size and type of welfare state, for instance - which may modulate the former relationship.

Given the aims of this study - to estimate the impact of skill levels, education and inequalities in the previous socioeconomic background on the probability of being unemployed - we apply a binomial logistic model to a subsample of individuals with labour experience. In this way, we are able to control for the effect of variables associated with the acquisition of competencies in the workplace and via on-the-job training. The dependant dichotomous variable takes a value of 1 if the individual is unemployed $^{6}$.

The independent variables introduced in our model are as follows:

- Individual characteristics: age and gender. Both characteristics are closely linked to the likelihood of employment in a number of European countries (see, for example, Heidenreich, 2015).

- Family socioeconomic background:

- Immigrant status: Previous studies have shown the relevance of place of birth as a determinant of labour market outcomes in European countries (Heath et al., 2008). Thus, we distinguish between natives, first generation immigrants and second generation immigrants. Additionally, we control for the language spoken by the

6 We checked the robustness of the analysis using a "long-term unemployment" variable too, the main results remaining stable. 
participants, introducing in the model a variable which takes a value of 1 if the individual's mother tongue is official in that country. It was not possible to incorporate, however, information on the time that had elapsed since the person migrated.

- Maximum parental level of education: Maximum level of education completed by his/her parents. This comprises a set of three dummy variables for the following levels: lower secondary education, higher secondary education and higher education. Parental education can affect the individual's likelihood of finding a workplace through a number of indirect channels (Chevalier et al. 2013).

- Current family situation: Labour economists and demographers have described the close link between family situation and labour market decisions (Neels et al., 2013, Schaller, 2013). Consequently, we introduce two dichotomous variables. The first variable takes value 1 if the person is married or lives with his/her partner and, the second, if the individual has children.

- Labour market participation/ professional profile: years of working experience, economic sector (primary sector, industry, construction and services) and a dichotomous variable which takes value 1 if the person was working in the public sector at the time of the interview or if he/she had his/her last job in the public sector.

- Literacy skills ${ }^{7}$ as measured by PIAAC-2013, using a 0 to 500 points scale, with a standard deviation of 50 . These skills measure the ability to understand, evaluate, use and engage with written text to develop one's knowledge and potential and to participate in society.

- Educational level: maximum level of formal education completed by the individual (six categories).

7 Sensitivity analyses were performed using numeracy skills, the main results, which are available upon request, remaining unaltered. 
The correspondence between workers' educational level and productivity - closely linked to their level of skills - may vary depending on the extent of the signalling role of education. We therefore have to eliminate the competencies from the signalling function of education. We do so by incorporating a proxy of skills instead of the educational level variable. This latter variable is used in the second part of the analysis.

A summary with the main descriptive statistics of the variables can be found in Table 1 .

<INSERT TABLE I AROUND HERE>

We therefore estimate the following model,

$$
U_{i j}=\beta_{0}+\beta_{1} \cdot X_{i j}+\beta_{2} \cdot Y_{i j}+\beta_{3} \cdot Z_{i j}+\beta_{4} \cdot L_{i j}+\beta_{5} \cdot S_{i j}+\varepsilon_{i j}
$$

where $U_{\mathrm{ij}}$ is the outcome of interest - unemployment status - for individual $i$ in jurisdiction $j ; X_{i j}$ is a set of individual characteristics; $Y_{i j}$ and $Z_{i j}$ are family background and current family characteristic covariates, respectively; $L_{\mathrm{ij}}$ is the professional profile of the individual; $S_{\mathrm{ij}}$, the literacy skills of the adult; and $\varepsilon_{\mathrm{ij}}$ is an error term.

\section{Analysis of the determinants of the probability of unemployment}

This section presents the results of the analyses identifying the determinants of being unemployed in 19 European and 5 non-European jurisdictions. We focus specifically on the effects of skills and family background in addressing our main research questions. Results from the logistic regressions are presented in Table 2. All results are discussed introducing the ceteris paribus clause; that is, assuming all other variables remain constant. The first result of interest - albeit variable in intensity - is the negative 
association between literacy skills and the probability of being unemployed in most jurisdictions. Austria, Northern Ireland and Russia, and Korea and Japan are, respectively, the European and non-European exceptions to this pattern. In this sense, it is worth mentioning that Austria, Japan and Korea are among the OECD's economies with the lowest rates of unemployment. In these countries, the chances of being included in the small group of unemployed adults seem to be less closely related to the level of skills than in all the other jurisdictions.

<INSERT TABLE II AROUND HERE>

The two individual variables introduced in the analysis are age and gender. The relationship between age and risk of unemployment seems to be unequivocal: older adults face a higher risk of unemployment in all jurisdictions except Austria. This is consistent with the pattern described for Austria by Eichhorst et al. (2014), which combined relatively low youth unemployment rates - for EU standards - with the second lowest elderly unemployment rates in the EU during the 2008-2012 period.

The effect of gender is less homogeneous. With all other variables remaining constant, the risk of unemployment is only higher for women in Italy and Slovakia; in 14 jurisdictions, there are no significant differences by gender; and, in the remaining eight, men face a higher risk of unemployment. This heterogeneity of situations is explained by differences in the economic cycle in each jurisdiction (for example, in 2012, Southern European countries were, on average, in a worse economic situation than their Northern counterparts); the previous level of integration of women in the active population; cultural patterns typifying labour market entry and exit during periods of economic turmoil; and the distribution of workers by gender in those industries most affected by the economic crisis in each jurisdiction. 
If we examine the family background variables, the country of origin of the adult does not seem to be a relevant determinant of unemployment in 14 of the 24 jurisdictions. There are, however, signs of labour market discrimination of first-generation immigrants in Austria, Denmark, Holland and Ireland, of second-generation immigrants in the Czech Republic, France, Slovakia and the United States, and of both first and secondgeneration immigrants in Spain, Estonia and Belgium (Flanders). This seems to be in line with Dustmann et al. (2010), who described greater unemployment responses to economic shifts for immigrants, being greatest for non-OECD low-skilled immigrants.

It is also worth mentioning that adults whose parents had completed higher education faced a lower risk of being unemployed in eight jurisdictions. The channels through which this variable, proxy for socio-cultural status, may be operating at adult ages enhanced health status, family access to privileged social circles, among others remains however unclear and deserves further research.

In order to obtain a clearer picture of the impact of previous inequalities, we recalculated the same model presented in Table 2, but we substituted the parental education dummies for a continuous variable that measures parental education in years. The coefficients linked to this new variable are shown in Figure 4. These coefficients are statistically non-significant for 14 jurisdictions which include, among others, three of the four Nordic countries, three Central European countries; two Benelux states and the two East Asian countries in the sample. These results support those reached by Paccagnella (2015), who showed that, in some countries, family background generates differences in the labour market outcomes not only through wages, but also through the likelihood of being employed.

<INSERT FIGURE 4 AROUND HERE> 
Being married or living as a couple is linked to a lower risk of unemployment in all the jurisdictions except Russia. The consistency of this result should, however, be interpreted with caution due to the possibility of endogeneity. For example, Schaller (2012) describes that both marriage and divorce rates move pro-cyclically. The situation is less clear when we examine the effect of having children. In cases such as Denmark, France, Flanders or Japan, those with children have a lower risk of unemployment. In contrast, having children in countries such as Ireland, Italy, French-speaking Canada and Poland raises the chances of being unemployed.

A consistent pattern is also identified when we observe the results related to labour market experience. Coefficients are negative and statistically significant for all the jurisdictions. This result shows labour market experience cushions the impact of age on unemployment.

We conclude this review of the determinants of unemployment by analysing a labour market demand factor, that of the economic sector. Interestingly, working in the construction sector implies a higher risk of unemployment in 12 jurisdictions. As expected, they include such countries as Ireland and Spain, which have experienced dramatic falls in the economic activity of this sector. The opposite situation is observed in Japan, while the coefficients for the 11 remaining jurisdictions are statistically nonsignificant. Workers in the primary sector in Flanders, Slovakia, Estonia, Russia and French-speaking Canada have a higher risk of unemployment than those in the services sector, while the opposite is the case for the Irish, the Spaniards and Czechs.

Finally, industrial workers in Germany and the Czech Republic are less likely to be unemployed than workers in their respective services sector. This, however, is not the case for countries where the economic crisis has had a marked impact on industrial production, including Austria, Belgium, France, Slovakia, Russia and the United States. 
The effect of being a public sector worker is, as expected, negative for a majority of the analysed jurisdictions. The public sector variable has a non-significant effect only in the Czech Republic, Germany, England, Slovakia, Japan and Korea.

We now turn to compare the effect of two alternative human capital proxies on the risk of unemployment: first, literacy skills, the variable employed throughout the analysis; and, the maximum formal educational attainment of the adult, a commonly accepted measure of human capital that may, however, be polluted by the signalling function of educational certificates. We therefore modified the model presented in the methodology section, the literacy skills variable being substituted by the formal educational attainment of the person, measured in years. We then re-estimated the model for the 24 jurisdictions. Unsurprisingly, the results obtained in both estimations were similar to those presented in Table 2 and are available upon request. However, we were particularly interested in establishing the differences that emerge when using these two alternative variables.

Figure 5 shows the close link between the two variables, with the coefficients of literacy and the years of education for the 24 jurisdictions being represented on the $\mathrm{X}$ and $\mathrm{Y}$ axes, respectively. As can be seen, there is a close association between both variables $\left(R^{2}=0.4443\right)$. Figure 5 can be interpreted as follows: the farther we move from the point of origin, the greater the importance of human capital in determining the risk of unemployment. For the four countries laying in the shaded area (Korea, Japan, Austria and Russia) both variables - reading skills and number of years of education - are statistically non-significant. In contrast, human capital plays a central role in determining unemployment status in countries such as Denmark, Germany and Sweden.

\section{$<$ INSERT FIGURE 5 AROUND HERE>}


Finally, one of the objectives of this article was to disentangle the extent of the effects of human capital and signalling theories of education. Figure 5 is particularly useful for this purpose. In countries lying above the regression line, the effect of skill levels exceeds the effect of formal education, while the opposite holds for countries below this line. Therefore, the explanatory power of human capital theory seems to be predominant in the case of the former, while the signalling function of education is more relevant for the latter countries. Figure 5 shows that some English-speaking jurisdictions such as the United States, English-speaking Canada and Ireland lie above the line, as do France, Spain and Italy. In all these cases, the level of skills seems to have a stronger effect than educational level on the risk of unemployment. In other words, the signalling function of education seems to be weaker in these countries. The opposite situation is found in, among others, Scandinavian and former Socialist countries. The identification of these patterns opens the door to future national-level case studies that might provide researchers with a better understanding of this issue.

\section{Conclusions}

Unemployment rates increased throughout Europe during the Great Recession, these increases being heterogeneous across countries and economic sectors. In turn, unemployment has affected the efficiency of European economies, wasting human capital and depressing aggregate demand, while it has exacerbated inequality and poverty levels. A remarkable characteristic of this crisis is that unemployment has hit those workers with low educational attainment the hardest. Two complementary theories have been suggested for explaining why employers prefer more highly educated workers. On the one hand, human capital theory suggests employers prefer the most productive individuals, education being an important channel through which workers can 
enhance their productivity. On the other hand, the signalling theory claims that the educational level attained by the individual operates as a signal for identifying those workers that might have the highest productivity (independent of whether this productivity has been acquired through education). PIAAC-2013 provides a unique chance for analysing the impact of skills - proxy for productivity - on the mechanisms that determine access to the labour market. It also allows us to isolate the effect of skills from the signalling function of education.

An initial cross-sectional analysis of the relationship between skills and unemployment has shown that countries with a higher mean level of skills tend to have lower unemployment rates. Although there is a need to exercise some caution, given the methodological limitations of our approach, this evidence has enabled us to formulate the following hypothesis: there is a long-term cumulative effect of human capital in those countries with higher levels of competencies. This effect may progressively increase their productive capacity. We have subsequently considered the role of education and training policies in raising the level of skills and facilitating the creation of new workplaces. The effectiveness of these policies, however, depends on the existence of a previous stock of physical capital (although, in the long term, one way to attract physical capital to a country might be by accumulating human capital - East Asian countries, such as South Korea, serve as a good example). In the light of these hypotheses, we have sought to provide an answer to the following questions: (1) What importance do skills have for labour market status? and (2) What is the effect of previous economic and sociocultural inequalities on labour market status? We have analysed these issues by applying logistic regression techniques to PIAAC-2013 data for 19 European and 5 nonEuropean jurisdictions.

In response to the first research question, our results point in the same direction as Abrassart (2013) and highlight the fact that skill levels are central to explaining 
unemployment in all the European countries in our sample except Russia. High levels of literacy (our proxy for productivity) seem to prevent workers losing their employment status in 19 out of 24 jurisdictions. This preventive effect is especially strong in Sweden and, interestingly, in a high-unemployment country such as Spain. This outcome is especially clear when we estimate an alternative model in which the years of formal education completed by a worker were used instead of literacy skills. Combining the results of the original and alternative models allows us to identify those labour markets that are most sensitive to human capital - most notably, Spain, Sweden, Germany, Denmark and the US. Additionally, we have provided evidence related to a further issue: labour markets in South European and English-speaking countries seem to behave in a similar way to that predicted by human capital theory; that is, in these countries skill levels are more important than having a formal educational qualification in accounting for unemployment.

In response to the second research question - the impact of family background inequalities on current labour status, we have identified at least two axes of inequality. First, in most jurisdictions, the family's sociocultural background does not have a direct impact on the probability of being unemployed. However, it is worth emphasizing the existence of an indirect effect, as an individual's sociocultural origin is a significant determinant of their skill levels which, at the same time, are closely related to their labour market status. Second, immigrant status increases the risk of unemployment in nine European jurisdictions. Controlling for other family background and individual characteristics, this result suggests the existence of discrimination by country of origin. It should be stressed that our analysis examines the risk of unemployment, and does not assess the type of job or the working conditions of those who are employed.

In measuring the skills of the adult population, PIAAC has opened the door to a better understanding of the relationship between skills, education and labour markets. While 
we readily acknowledge certain methodological limitations in our approach (specifically, we perform our analysis using just one type of skill and we exclude from the study those adults with no working experience, which may be of relevance in countries with a large number of people seeking their first job) and the fact that we do not consider noncognitive skills, we believe this study represents an initial step in the development of further research hypotheses and the design of successful education and training policies and labour market reforms in Europe. For example, in the case of Spain, the identification of the relevance of the number of years of experience may be linked to the existence of a segmented insider-outsider labour market (Bentolila et al., 2012), with skills probably playing an atypical role in markets of this kind. Introducing systems for the recognition and validation of skills acquired through non-formal and informal training may also be especially relevant for those countries where human capital seems to be more important -this is in line with the instructions stated by Resolution 2010/C 137/01 and Recommendation 2012/C 398/01 of the European Council-. We therefore call for the development of country-level studies that might shed further light on the patterns identified in this article.

\section{References}

ABRASSART, A. (2013). Cognitive Skills Matter: The Employment Disadvantage of LowEducated Workers in Comparative Perspective, European Sociological Reviewy, 29(4), pp. 707-719.

ADALET MCGOWAN, M. \& ANDREWS, D. (2015) Skill Mismatch and Public Policy in OECD Countries, OECD Economics Department Working Papers, 1210.

AGNELLO, L. \& SOUSA, R.M. (2012) How do banking crises impact on income inequality?, Applied Economic Letters, 19(15), pp. 1425-1429.

ALLEN, J., VAN DER VELDEN, R. \& LEVELS, M. (2013). Skill Mismatch and Use in Developed Countries: Evidence from the PIAAC Study. ROA Research Memorandum, RM/13/061.

BARRO, R.J. (1996) Determinants of Economic Growth: A Cross-Country Empirical Study, NBER Working Paper, 5698. 
BECKER, G.S. (1962). Investment in Human Capital: A Theoretical Analysis, Journal of Political Economy, 70(5), pp. 9-49.

BEHAGHEL, L., CAROLI, E. \& ROGER, M. (2014). Age-biased Technical and Organizational Change, Training and Employment Prospects of Older Workers. Economica, 81, pp. 368-389

BENTOLILA, S., DOLADO, J.J. \& JIMENO, J.F. (2012) Reforming an insider-outsider labor market: The Spanish experience, IZA Journal of European Labor Studies, 1(4). DOI: 10.1186/2193-9012-1-4.

BOSCH, M. \& ESTEBAN-PRETEL, J. (2012) Job creation and job destruction in the presence of informal markets, Journal of Development Economics, 98, pp.270-286.

CHEVALIER, A., HARMON, C., O'SULLIVAN, V. \& WALKER, I. (2013). The impact of parental income and education on the schooling of their children, IZA Journal of Labor Economics, 2(1), pp. 1-22.

CLARK, D. \& MARTORELL, P. (2014) The Signaling Value of a High School Diploma, Journal of Political Economy, 122(2), pp. 282-318.

DE BEER, P. (2012) Earnings and income inequality in the EU during the crisis, International Labour Review, 151(4), pp. 313-331.

DICKSON, H. \& HARMON, C. (2011) Economic Returns to Education: What We Know, What We Don't Know, and Where We Are Going - Some Brief Pointers, Economics of Education Review, 30(6), pp. 1118-1122.

DONADO, A \& WÄLDE, K. (2012) How trade unions increase welfare, The Economic Journal, 122, pp. 990-1009.

DUSTMANN, C., GLITZ, A. \& VOGEL, T. (2010). Employment, wages, and the economic cycle: Differences between immigrants and natives, European Economic Review, 54, pp. 1-17.

EICHHORST, W., BOERI, T., DE COEN, A., GALASSO, V., KENDZIA, M. \& STEIBER, N. (2014). How to combine the entry of young people in the labour market with the retention of older workers? IZA Journal of European Labor Studies, 3(19), pp. 1-23. DOI:10.1186/2193-9012-3-19

EUROPEAN COUNCIL (2010). Resolution of the Council and of the Representatives of the Governments of the Member States, meeting within the Council, on the active inclusion of young people: combating unemployment and poverty, 2010/C 137/0.

EUROPEAN COUNCIL (2012). Recommendation on the validation of non-formal and informal learning, 2012/C 398/01.

European Commission (2007) Communication from the Commission. Improving Knowledge Transfer between Research Institutions and Industry across Europe (Luxembourg, Office for Official Publications of the European Communities).

FLISI, S., GOGLIO, V., MERONI, E., RODRIGUES, M. \& VERA-TOSCANO, E. (2014) Occupational mismatch in Europe: Understanding overeducation and overskilling for policy making. JRC Science and Policy Reports, Report EUR 26618 EN. DOI: $10.2788 / 61733$

GEBEL, M. \& GIESECKE, J. (2011) Labor Market Flexibility and Inequality: The Changing Skill-Based Temporary Employment and Unemployment Risks in Europe, Social Forces, 90(10), pp. 17-19. 
GESTHUIZEN, M., SOLGA, H, \& KÜNSTER, R. (2011) Context Matters: Economic Marginalization of Low-Educated Workers in Cross-National Perspective, European Sociological Review, 27(2), pp. 264-280.

GOTTSCHALK, P. \& SMEEDING, T.M. (1997) Cross-National Comparisons of Earnings and Income Inequality, Journal of Economic Literature, 35(2), pp. 633-687.

HANUSHEK, E. A., SCHWERDT, G., WIEDERHOLD, S. \& WOESSMANN, L. (2015) Returns to skills around the world: Evidence from PIAAC, European Economic Review, 73, pp.103-130.

HEATH, A.F., ROTHON, C. \& KILPI, E. (2008). The Second Generation in Western Europe: Education, Unemployment, and Occupational Attainment. Annual Review of Sociology, 34, pp. 211-235. DOI: 10.1146/annurev.soc.34.040507.134728

HEIDENREICH, M. (2015). The end of the honeymoon: The increasing differentiation of (long-term) unemployment risks in Europe, Journal of European Social Policy, 25(4), pp.393-413.

JÄNTTI, M. \& JENKINS, S. P. (2015) Income mobility, in A.B. ATKINSON \& F. BOURGUIGNON (Eds) Handbook of Income Distribution, vol. 2, pp. 807-935 (Amsterdam, North Holland)

KRUEGER, A.B. \& LINDAHL, M. (2001) Education for Growth: Why and for Whom?, Journal of Economic Literature, 39(4), pp. 1101-1136.

MINCER, J. (1958) Investment in Human Capital and Personal Income Distribution, Journal of Political Economy, 66(4), pp. 281-302.

MORGADO, A., SEQUEIRA, T. N., SANTOS, M., FERREIRA-LOPES, A. \& BALCAOREIS, A. (2015) Measuring labour mismatch in Europe. Social Indicators Research. DOI: $10.1007 / \mathrm{s} 11205-015-1097-0$

NEELS, K., THEUNYNCK, Z. \& WOOD, J. (2013). Economic recession and first births in Europe: recession-induced postponement and recuperation of fertility in 14 European countries between 1970 and 2005, Journal of Public Health, 58, pp. 43-55. DOI 10.1007/s00038-012-0390-9

OECD (2011) Divided we Stand: Why Inequality Keeps Rising (Paris, OECD).

OECD (2013a) Strengthening Local Skills Strategies, OECD Skills Strategy Spotlight Better Skills, Better Jobs, Better Lives, 5.

OECD (2013b) OECD Skills Outlook 2013 First Results from the Survey of Adult Skills (Paris, OECD).

OECD (2013c) What Students Know and Can Do (Paris, OECD).

OECD (2014a) OECD Employment Outlook (PIAAC) (Paris, OECD).

OECD (2014b) Technical Report of the Survey of Adult Skills (PIAAC) (Paris, OECD).

PACCAGNELLA, M. (2015) Skills and Wage Inequality: Evidence from PIAAC, OECD Education Working Papers, 114.

PSACHAROPOULOS, G. \& PATRINOS, H.A. (2004) Returns to investment in education: a further update, Education Economics, 12(2), pp.111-134.

REICH, R. (2010). Aftershock. The Next Economy and America's Future (NY, Vintage Books).

RICCI, F. \& ZACHARIADIS (2013). Education Externalities on Longevity, Economica, 80, pp.404-440. 
SCHALLER, J. (2013). For richer, if not for poorer? Marriage and divorce over the business cycle. Journal of Population Economics, 26, pp. 1007-1033. DOI: 10.1007/s00148-012-0413-0

SPENCE, M. (1976) Job Market Signaling, The Quarterly Journal of Economics, 87(3), pp. 355-374.

STRAUSS, S. \& LEUZE, K. (2013) Further Education of Higher Education Graduates: The More, the Better? European Journal of Education, 48(3), pp.436-453.

\section{Appendix}

$<$ INSERT TABLE A.1 AROUND HERE>

$<$ INSERT TABLE A.2 AROUND HERE> 
FIGURE 1. Evolution of the seasonally adjusted quarterly unemployment rates of the 25to 64-year-old population of the EU-28 area between 2008 and 2014 (Eurostat).

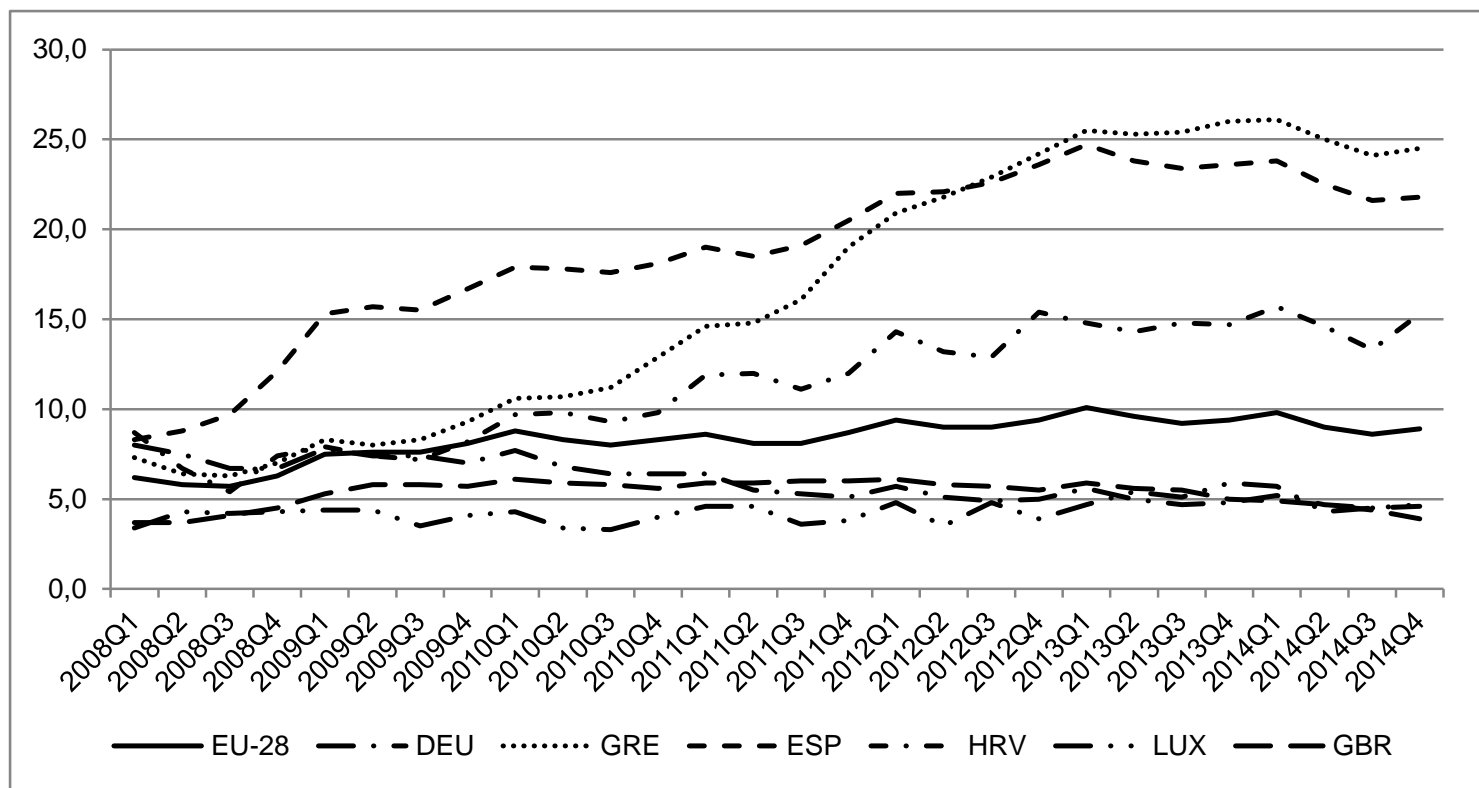

Note: Germany (DEU), Luxembourg (LUX) and the United Kingdom (GBR) were the EU-28 countries with the lowest unemployment rates by December 2014; the opposite was the case for Spain (ESP), Greece (GRE) and Croatia (HRV). 
FIGURE 2. Unemployment rates of the EU by educational levels (28 countries); 20022014 (Eurostat)

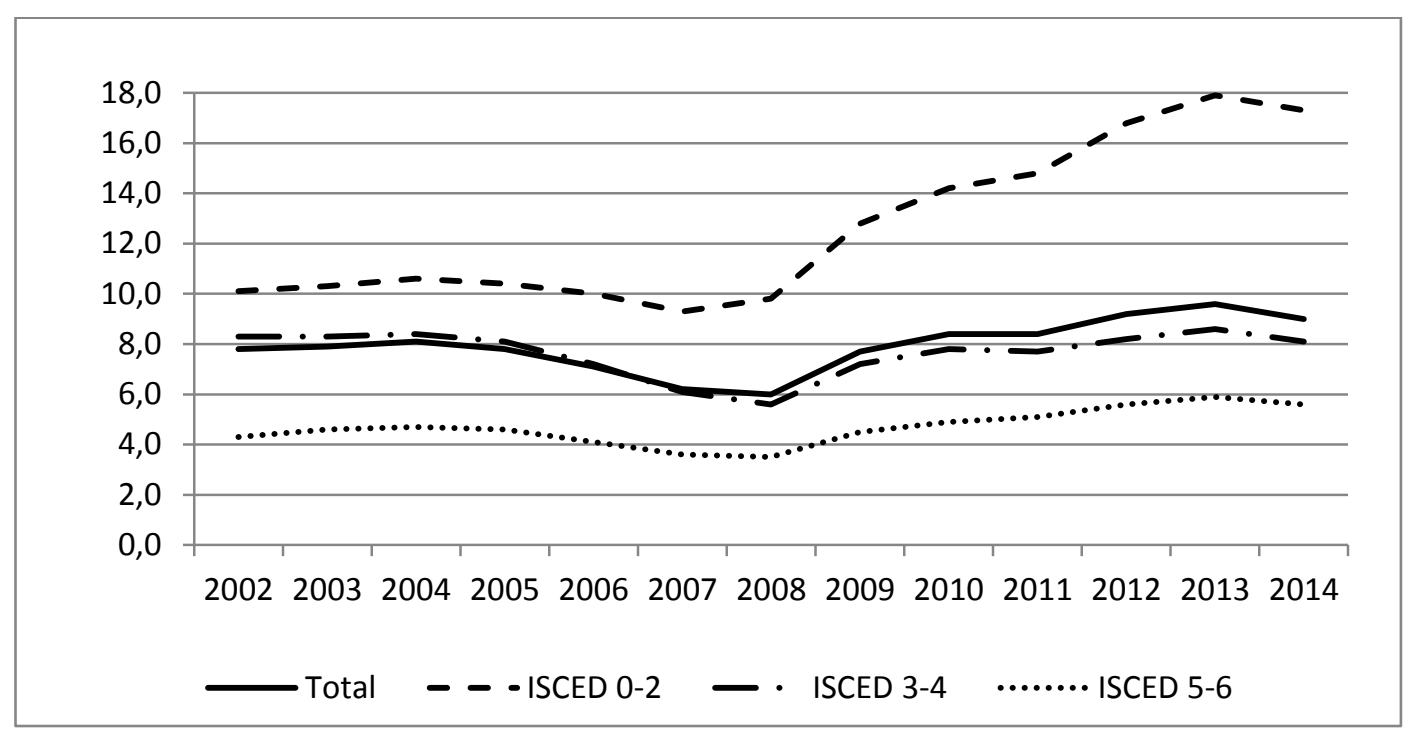


FIGURE 3. Mean literacy skills in PIAAC-2013 and 2012 unemployment rates (24 jurisdictions) (PIAAC-2013 and EUROSTAT).

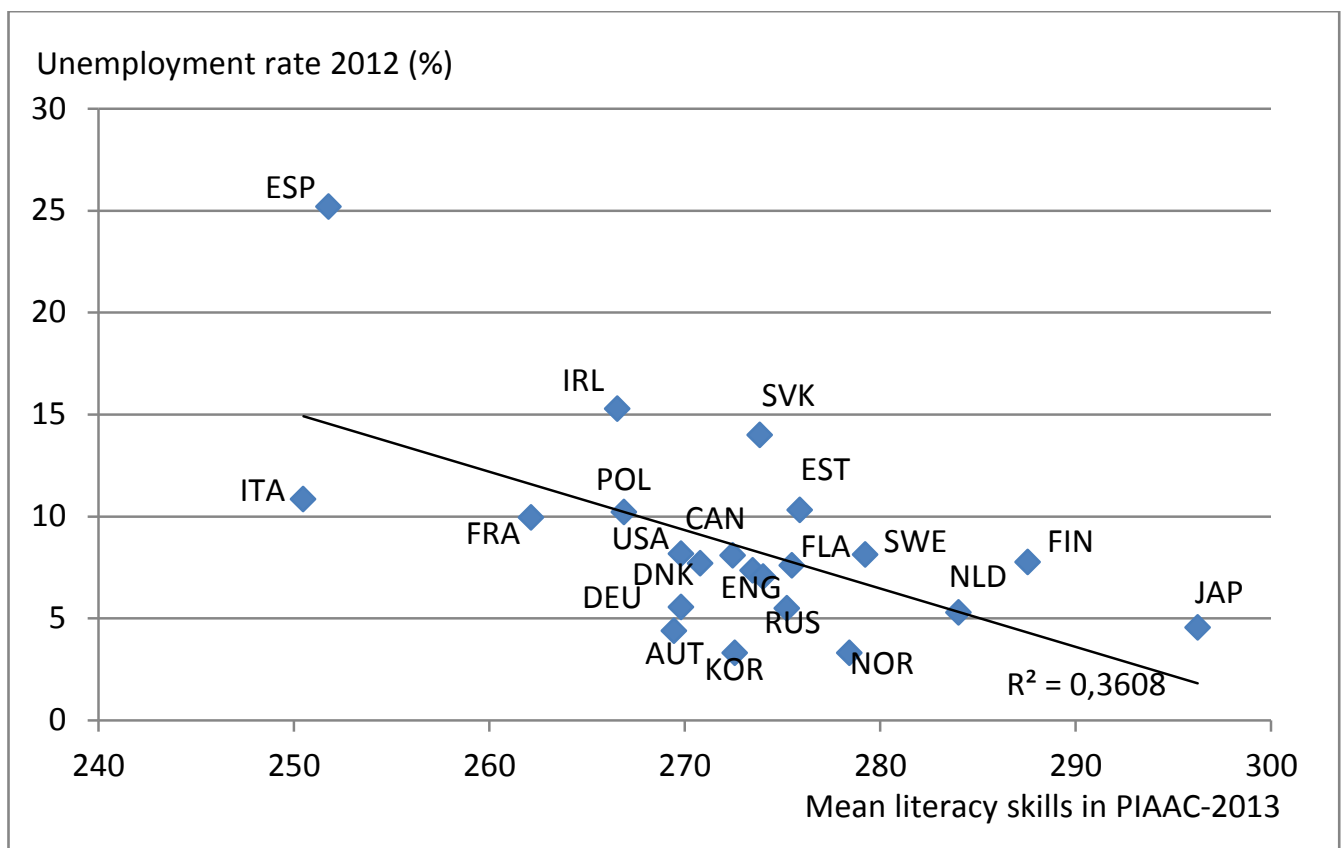


FIGURE 4. Effect of parental education on the probability of being unemployed; coefficients from a logistic regression model (PIAAC-2013).

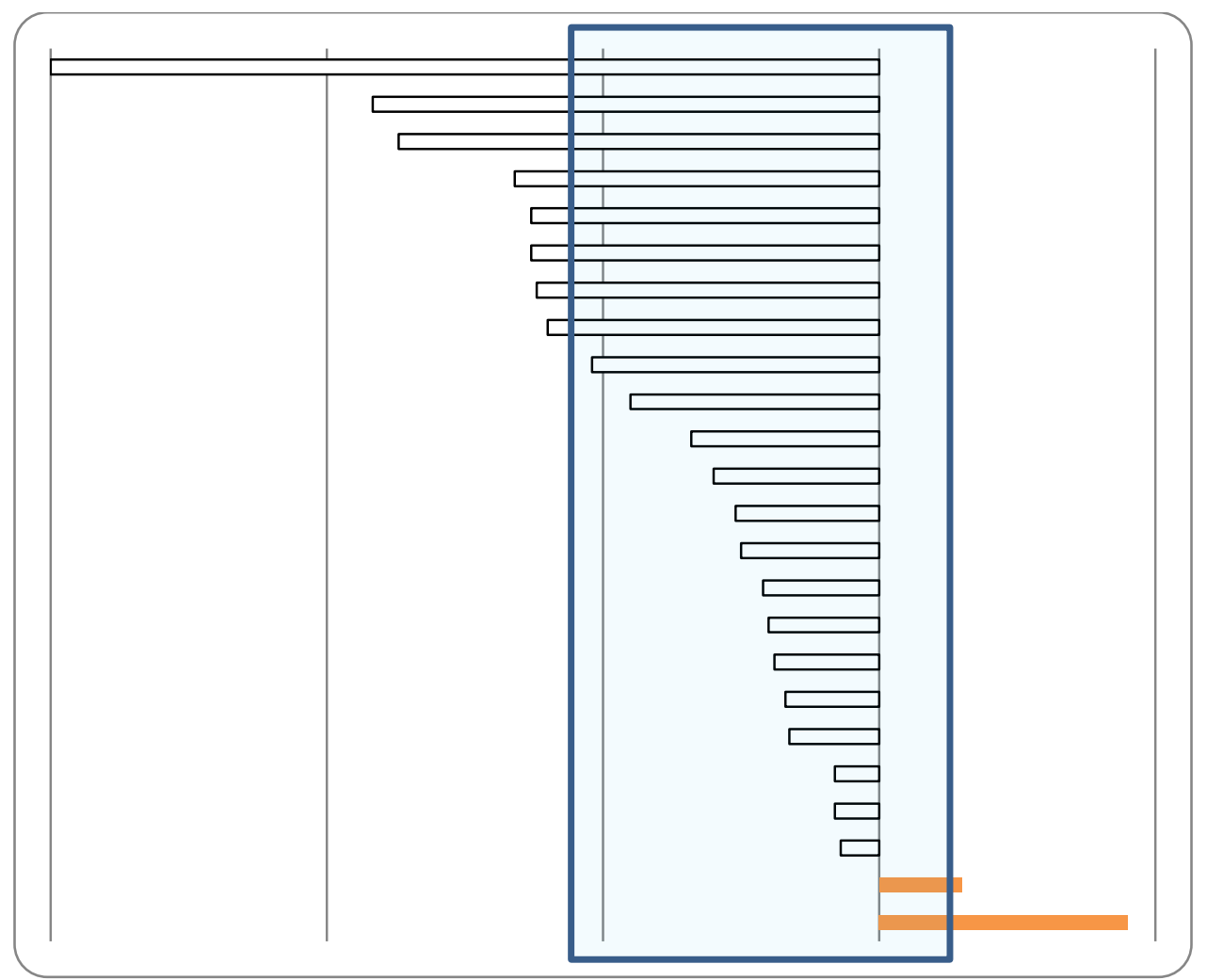

Note: Coefficients with values within the shaded area are statistically not-significant. 
FIGURE 5. Effects of formal education (in years) and literacy skills (as measured in PIAAC-2013) on the probability of being unemployed; coefficients from logistic regressions for 24 jurisdictions (PIAAC-2013).

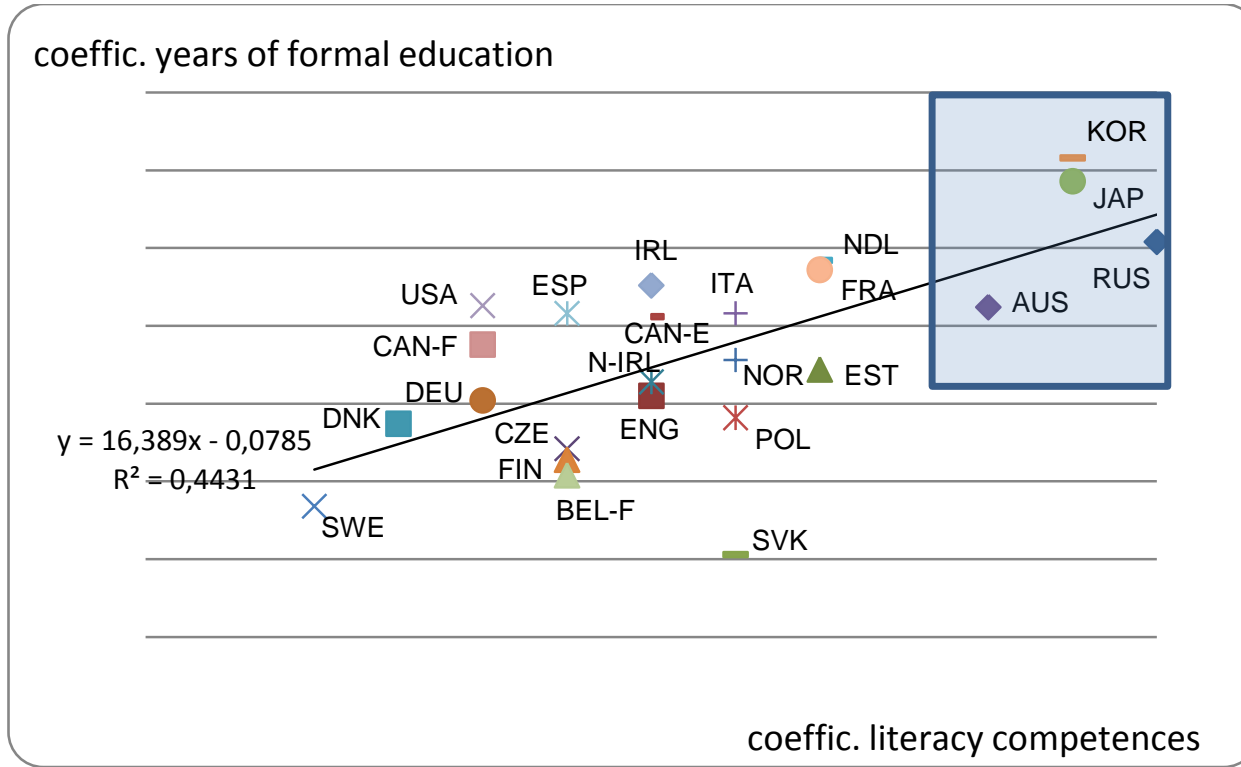

Note: Coefficients with values within the shaded area are statistically not-significant. 
TABLE I. Summary statistics of variables included in the regressions

\begin{tabular}{lrrrr}
\hline & Mean & SD & Min & Max \\
\hline Reading skills & 275.90 & 43.92 & 23.57 & 415.64 \\
Age (years) & 41.19 & 11.87 & 65 \\
Gender (1, if man) & 0.55 & 0.50 & 0 & 1 \\
Family background: Non-immigrant & 0.87 & 0.75 & 0 & 1 \\
Family background: First-generation immigrant & 0.10 & 0.30 & 0 & 1 \\
Family background: Second-generation immigrant & 0.03 & 0.15 & 0 & 1 \\
Mother tongue (1, if official language in the country) & 0.90 & 0.9 & 0 & 1 \\
Maximum parental education: 1, if lower secondary & 0.29 & 0.44 & 0 & 1 \\
Maximum parental education: 1, if higher secondary & 0.42 & 0.49 & 0 & 1 \\
Maximum parental education: 1, if higher education & 0.29 & 0.44 & 0 & 1 \\
Civil status (1, if married or lives with couple) & 0.66 & 0.47 & 0 & 1 \\
Children (number) & 1.60 & 1.12 & 0 & 25 \\
Labour market experience (in years) & 19.27 & 12.01 & 0 & 55 \\
Economic sector: Primary & 0.03 & 0.16 & 0 & 1 \\
Economic sector: Industry & 0.17 & 0.37 & 0 & 1 \\
Economic sector: Construction & 0.08 & 0.26 & 0.44 & 0 \\
Economic sector: Services & 0.72 & & 0 & 1 \\
\hline
\end{tabular}

Source: self-elaboration from PIAAC-2013 microdata.

Note: mean statistics for a sample of 24 jurisdictions. Country-level summary statistics available upon request. 
TABLE II. Determinants of the probability of being unemployed in 24 jurisdictions. Results of logit regressions applied to PIAAC-2013.

\begin{tabular}{|c|c|c|c|c|c|c|c|c|}
\hline & AUT & CZE & DEU & DNK & ENG & ESP & EST & FLA \\
\hline Reading skills & -0.002 & $-0.007^{\star \star}$ & $-0.007^{\star * *}$ & $-0.009^{* * *}$ & $-0.006^{\star \star \star}$ & $-0.007^{* * *}$ & $-0.004^{\star * *}$ & $-0.007^{\star \star \star}$ \\
\hline Age (years) & 0.040 & $0.078^{* \star *}$ & $0.058^{* * *}$ & $0.047^{\star * *}$ & $0.044^{\star \star *}$ & $0.031^{\star \star \star}$ & $0.075^{\star \star *}$ & $0.064^{\star * *}$ \\
\hline Gender $(1=$ man $)$ & -0.399 & 0.078 & $0.445^{\star *}$ & -0.146 & $0.418^{\star *}$ & $0.216^{\star \star}$ & 0.211 & 0.1138 \\
\hline \multicolumn{9}{|l|}{$\begin{array}{l}\text { Family background. } \\
\text { Reference: non-immigrant }\end{array}$} \\
\hline First-generation immigrant & $1.149^{* * *}$ & -0.167 & -0.060 & $0.662^{*}$ & -0.225 & $0.344^{\star *}$ & $0.818^{* * *}$ & $0.882^{* *}$ \\
\hline $\begin{array}{l}\text { Second-generation immigrant } \\
\text { Mother tongue is official in this }\end{array}$ & 0.761 & $1.891^{* * *}$ & -0.352 & -0.156 & -0.715 & $1.064^{*}$ & $0.534^{* * *}$ & $1.663^{\star * *}$ \\
\hline country & & -0.153 & $-0.680^{*}$ & $1.007^{\star \star *}$ & -0.037 & 0.315 & 0.477 & 0.417 \\
\hline \multicolumn{9}{|l|}{$\begin{array}{l}\text { Maximum parental education. } \\
\text { Reference: lower secondary }\end{array}$} \\
\hline Higher secondary & 0.184 & 0.565 & 0.121 & -0.102 & $-0.476^{\star}$ & $-0.258^{\star \star}$ & $-0.275^{*}$ & $-0.401^{*}$ \\
\hline Higher education & -0.171 & -0.051 & 0.158 & $-0.356^{\star \star}$ & $-0.770^{\star \star}$ & -0.114 & $-0.409^{\star *}$ & -0.139 \\
\hline Married or living as a couple & $-0.909^{* \star *}$ & $-0.446^{*}$ & $-1.256^{* * *}$ & $-0.665^{\star \star *}$ & $-0.781^{* * *}$ & $-0.385^{\star * *}$ & $-0.661^{\star * *}$ & $-0.813^{* * *}$ \\
\hline Children & -0.001 & 0.070 & -0.009 & $-0.137^{*}$ & -0.072 & -0.053 & -0.017 & $-0.174^{*}$ \\
\hline $\begin{array}{l}\text { Labour market experience } \\
\text { (years) }\end{array}$ & $-0.058^{* * *}$ & $-0.105^{* * *}$ & $-0.064^{* * *}$ & $-0.083^{* \star *}$ & $-0.072^{\star \star *}$ & $-0.058^{\star * *}$ & $-0.104^{* * *}$ & $-0.088^{* * *}$ \\
\hline \multicolumn{9}{|l|}{$\begin{array}{l}\text { Economic Sector. Reference: } \\
\text { Services }\end{array}$} \\
\hline Primary & & $-1.017^{\star \star}$ & & 0.081 & 0.050 & $-0.462^{* *}$ & $0.759^{\star * *}$ & $1.026^{* *}$ \\
\hline Industry & $0.722^{\star *}$ & $-0.486^{\star *}$ & $-0.440^{*}$ & 0.004 & 0.204 & 0.070 & 0.054 & $0.489^{* *}$ \\
\hline Construction & $1.071^{* * *}$ & -0.301 & -0.054 & $0.340^{*}$ & 0.296 & $0.884^{* * *}$ & $0.748^{* * *}$ & -0.543 \\
\hline Public sector & $-0.963^{*}$ & -0.358 & -0.540 & $-0.303^{* *}$ & -0.384 & $-0.275^{\star *}$ & $-0.656^{* * *}$ & $-0.560^{*}$ \\
\hline Pseudo- $R^{2}$ & 0.104 & 0.069 & 0.104 & 0.096 & 0.083 & 0.083 & 0.095 & 0.123 \\
\hline Number of observations & 2,268 & 3,368 & 2,257 & 4,983 & 2,808 & 3,892 & 4,854 & 3,206 \\
\hline
\end{tabular}

Source: self-elaboration from PIAAC-2013 microdata.

Note: where ${ }^{* * *},{ }^{* *}$ and ${ }^{*}$ denote, respectively, significance at 1, 5 and $10 \%$ levels. AUT: Austria; CZE: Czech Republic; DEU: Germany; DNK: Denmark; ENG: England; ESP: Spain; EST: Estonia; FLA: Belgium (Flanders). 
TABLE II (continues). Determinants of the probability of being unemployed in 24 jurisdictions. Results of logit regressions applied to PIAAC-2013.

\begin{tabular}{|c|c|c|c|c|c|c|c|c|}
\hline & FIN & FRA & IRL & ITA & NLD & N.IRL & NOR & SVK \\
\hline Reading skills & $-0.007^{\star * \star}$ & $-0.004^{\star * *}$ & $-0.006^{\star * *}$ & $-0.005^{\star *}$ & $-0.004^{* *}$ & -0.006 & $-0.005^{\star}$ & $-0.005^{\star *}$ \\
\hline Age (years) & $0.111^{\star * *}$ & $0.044^{* \star *}$ & 0.014 & $0.027^{\star *}$ & $0.0513^{\star * *}$ & $0.091^{\star * *}$ & $0.047^{\star \star \star}$ & $0.087^{\star \star *}$ \\
\hline Gender $(1=\operatorname{man})$ & $0.588^{* * *}$ & -0.126 & $0.452^{\star * *}$ & $-0.342^{*}$ & $0.357^{\star *}$ & $0.476^{*}$ & -0.098 & $-0.303^{* *}$ \\
\hline \multicolumn{9}{|l|}{$\begin{array}{l}\text { Family background. } \\
\text { Reference: non-immigrant }\end{array}$} \\
\hline First-generation immigrant & 0.228 & 0.105 & $0.380^{* *}$ & 0.109 & $0.716^{\star \star}$ & -1.062 & 0.183 & -0.911 \\
\hline $\begin{array}{l}\text { Second-generation immigrant } \\
\text { Mother tongue is official in this }\end{array}$ & 0.157 & $0.622^{\star * \star}$ & -0.701 & & 0.318 & & 1.195 & $-1.951^{* *}$ \\
\hline country & 0.156 & -0.212 & 0.165 & 0.160 & -0.177 & -0.411 & -0.425 & $-0.736^{* * *}$ \\
\hline \multicolumn{9}{|l|}{$\begin{array}{l}\text { Maximum parental education. } \\
\text { Reference: lower secondary }\end{array}$} \\
\hline Higher secondary & -0.133 & $0.267^{* *}$ & $-0.409^{* * *}$ & -0.287 & -0.027 & 0.327 & -0.147 & $-0.640^{* * *}$ \\
\hline Higher education & -0.208 & -0.198 & $-0.500^{\star \star *}$ & -0.451 & -0.405 & 0.276 & -0.240 & $-1.211^{\star \star \star}$ \\
\hline Married or living as a couple & $-1.119^{* * *}$ & $-0.891^{\star \star *}$ & $-0.725^{\star * *}$ & $-0.391^{\star *}$ & $-1.217^{\star * *}$ & $-1.093^{\star * *}$ & $-0.642^{* * *}$ & $-0.789^{* * *}$ \\
\hline Children & 0.041 & $-0.101^{*}$ & $0.110^{* *}$ & $0.145^{\star *}$ & -0.050 & -0.112 & -0.116 & 0.058 \\
\hline $\begin{array}{l}\text { Labour market experience } \\
\text { (years) }\end{array}$ & $-0.126^{* * *}$ & $-0.074^{* * *}$ & $-0.044^{* * *}$ & $-0.072^{\star \star *}$ & $-0.051^{* * *}$ & $-0.105^{\star \star \star}$ & $-0.086^{* * *}$ & $-0.118^{* * *}$ \\
\hline \multicolumn{9}{|l|}{$\begin{array}{l}\text { Economic Sector. Reference: } \\
\text { Services }\end{array}$} \\
\hline Primary & 0.023 & 0.485 & $-1.033^{\star *}$ & 0.040 & & & -0.133 & $0.647^{* *}$ \\
\hline Industry & 0.062 & $0.326^{* \star *}$ & 0.058 & 0.151 & -0.074 & 0.466 & 0.276 & $0.566^{\star * *}$ \\
\hline Construction & 0.319 & $0.443^{* *}$ & $1.529^{* * *}$ & $0.795^{\star * *}$ & 0.474 & $0.681^{*}$ & -0.523 & $1.023^{* * *}$ \\
\hline Public sector & -0.311 & $-0.577^{\star \star *}$ & $-0.789^{* * *}$ & $-0.974^{* * *}$ & $-0.536^{* *}$ & -0.662 & $-0.662^{\star \star *}$ & 0.020 \\
\hline Pseudo- $R^{2}$ & 0.131 & 0.105 & 0.137 & 0.093 & 0.102 & 0.127 & 0.111 & 0.120 \\
\hline Number of observations & 2,566 & 3,941 & 3,824 & 3,156 & 3,536 & 2,086 & 3,343 & 3,494 \\
\hline
\end{tabular}

Source: self-elaboration from PIAAC-2013 microdata.

Note: where ${ }^{* * *},{ }^{* *}$ and ${ }^{*}$ denote, respectively, significance at 1, 5 and $10 \%$ levels. FIN: Finland; FRA: France; IRL: Ireland; ITA: Italy; NLD: Netherlands; N.IRL: Northern Ireland; NOR: Norway; SVK: Slovakia. 
Table A.1. Activity and unemployment rates. Countries participating in the PIAAC.

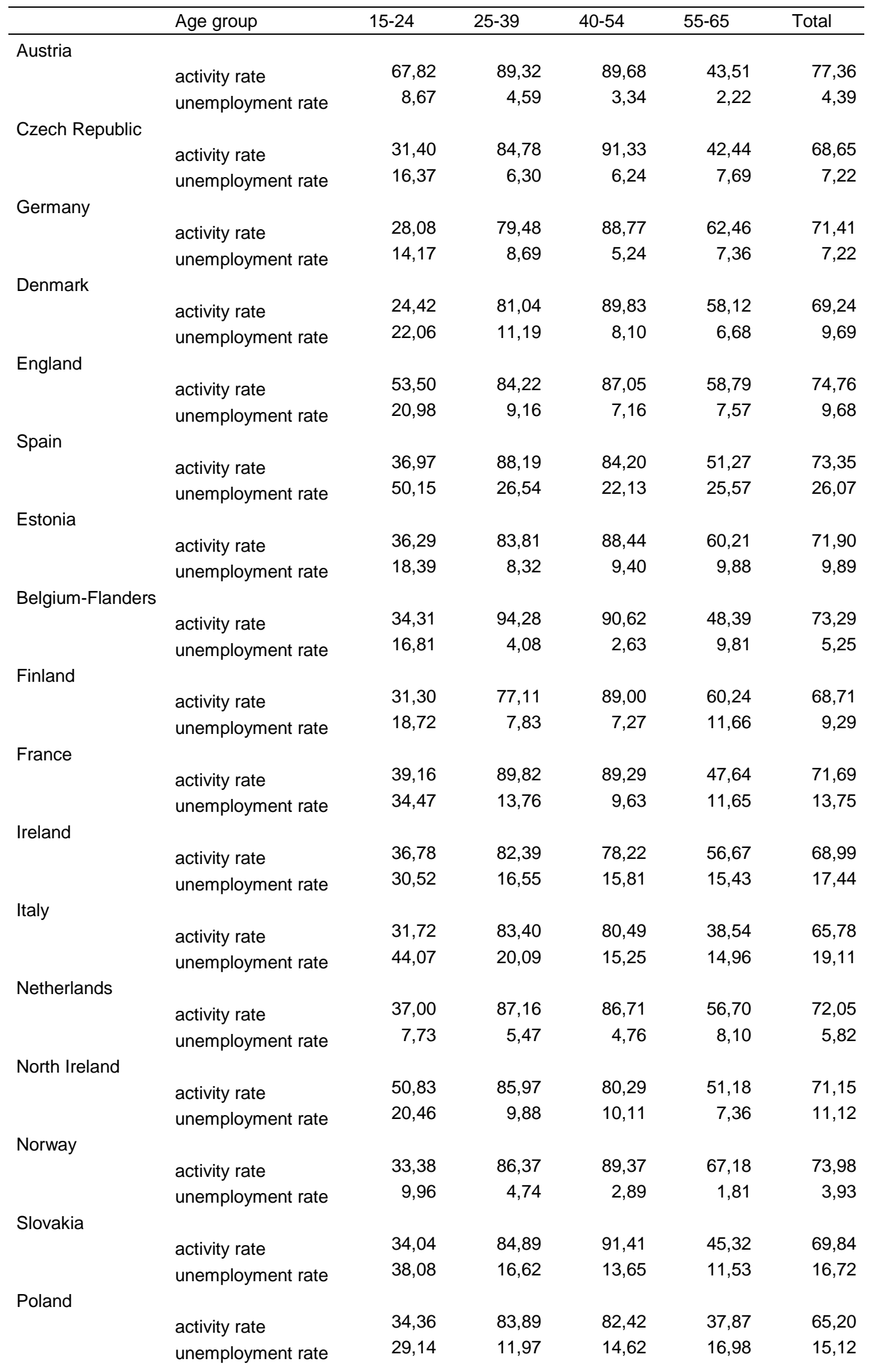

Russia 
activity rate $\quad 36,84$

82,32

16,09

10,76

85,47

37,77

66,80

unemployment rate

16,09

9,94

4,74

10,30 
Table A.1 (continued).

\begin{tabular}{|c|c|c|c|c|c|c|}
\hline & Age group & $15-24$ & $25-39$ & $40-54$ & $55-65$ & Total \\
\hline \multicolumn{7}{|l|}{ Sweden } \\
\hline & activity rate & 38,92 & 83,21 & 91,34 & 69,13 & 74,46 \\
\hline & unemployment rate & 22,74 & 7,35 & 5,83 & 6,71 & 8,13 \\
\hline \multicolumn{7}{|l|}{ Canada (Eng.) } \\
\hline & activity rate & 43,19 & 82,30 & 87,41 & 63,47 & 73,30 \\
\hline & unemployment rate & 13,60 & 7,40 & 6,70 & 5,67 & 7,47 \\
\hline \multicolumn{7}{|l|}{ Canada (Fr.) } \\
\hline & activity rate & 39,68 & 79,45 & 84,88 & 51,10 & 68,65 \\
\hline & unemployment rate & 9,17 & 5,33 & 6,38 & 5,62 & 6,15 \\
\hline \multicolumn{7}{|l|}{ Japan } \\
\hline & activity rate & 45,91 & 81,55 & 84,57 & 71,77 & 75,02 \\
\hline & unemployment rate & 9,95 & 4,24 & 4,07 & 12,96 & 6,71 \\
\hline \multicolumn{7}{|l|}{ Korea } \\
\hline & activity rate & 25,85 & 76,33 & 81,83 & 61,24 & 67,48 \\
\hline & unemployment rate & 10,35 & 5,49 & 3,08 & 8,57 & 5,22 \\
\hline \multicolumn{7}{|l|}{ USA } \\
\hline & activity rate & 51,94 & 82,76 & 83,58 & 64,71 & 73,80 \\
\hline & unemployment rate & 18,84 & 9,22 & 10,34 & 9,24 & 10,89 \\
\hline
\end{tabular}

Source: self-elaboration from PIAAC-2013 microdata. 
Table A.2. Average literacy competences of the employed and unemployed populations. Countries participating in the PIAAC.

\begin{tabular}{lrrr}
\hline & Employed & Unemployed & \multicolumn{1}{l}{ Total } \\
\hline & & & \\
Austria & 273,7 & 259,2 & 273,0 \\
Czech Republic & 276,4 & 266,2 & 275,6 \\
Germany & 272,9 & 247,7 & 271,0 \\
Denmark & 276,9 & 256,2 & 274,9 \\
England & 278,9 & 250,9 & 276,1 \\
Spain & 259,9 & 241,3 & 255,0 \\
Estonia & 278,5 & 264,0 & 277,1 \\
Belgium-Flanders & 281,2 & 257,2 & 279,9 \\
Finland & 293,5 & 270,7 & 291,4 \\
France & 266,0 & 252,4 & 264,1 \\
Ireland & 273,6 & 252,6 & 269,9 \\
Italy & 254,9 & 241,2 & 252,2 \\
Netherlands & 289,5 & 263,2 & 287,9 \\
North Ireland & 275,8 & 249,5 & 272,8 \\
Norway & 284,1 & 259,9 & 283,1 \\
Slovakia & 279,4 & 253,4 & 275,0 \\
Poland & 272,3 & 252,5 & 269,3 \\
Russia & 277,7 & 267,2 & 276,6 \\
Sweden & 286,2 & 259,1 & 284,0 \\
Canada (Eng.) & 278,8 & 257,0 & 277,2 \\
Canada (Fr.) & 273,3 & 248,7 & 271,8 \\
Japan & 298,1 & 287,9 & 297,4 \\
Korea & 271,6 & 267,2 & 271,4 \\
USA & 274,0 & 250,0 & 271,2 \\
\hline
\end{tabular}

Source: self-elaboration from PIAAC-2013 microdata. 